\title{
FLEXURAL BEHAVIORS OF SANDWICH COMPOSITES PRODUCED USING RECYCLED AND NATURAL MATERIAL
}

\author{
${ }^{*}$ H. Ersen BALCIOĞLU \\ Department of Mechanical Engineering, Uşak University, Turkey ersen.balcioglu@usak.edu.tr \\ (i) https://orcid.org/0000-0002-8579-5142
}

Received: 16.01.2018, Accepted: 27.05.2018

Research Article

*Corresponding author

DOI:10.22531/muglajsci.421813

\section{Abstract}

Recently, for making the low-cost engineering materials the use of natural fibers as reinforcement in polymers composites has brought forth a lot of interest. The use of natural products instead of synthetic materials reduces the amount of carbon released into the atmosphere. Nevertheless, reuse of used materials by recycled is important both for the environment and for economic reasons. In this study, flexural behaviors of sandwich composites manufactured by using natural and recycled material were investigated. In this context, 9 different core materials, which were made by using 3 different granules size (1 mm, $2 \mathrm{~mm}$ and $4 \mathrm{~mm}$ ) and 3 different core thickness ( $4 \mathrm{~mm}, 8 \mathrm{~mm}$ and $12 \mathrm{~mm}$ ), were manufactured from waste vehicle tires. After, sandwich composites were produced by combining the core materials with natural jute fabric reinforced laminated composites. In order to test the usability of the produced sandwich composite materials as building material, the flexural behaviors of the sandwich composite were investigated under three-point bending load. Test results show that flexural behavior of the material varies according to the granular size and thickness of the core material. Keywords: Sandwich composite, flexural modulus, flexural strength, recycling, natural fibers, granule size, core thickness

\section{GERİ DÖNÜŞTÜRÜLMÜŞ VE DOĞAL MALZEME KULLANILARAK ÜRETİLEN SANDVIÇ KOMPOZITLERÍNİN EĞİLME DAVRANIŞLARI}

Öz

Son yıllarda, düşük maliyetli mühendislik malzemeleri üretebilmek için polimer malzemelerde takviye olarak doğal fiberler kullanımı üzerine ilgi artmaktadır. Sentetik malzemeler yerine doğal ürünlerin kullanılması atmosfere salınan karbon miktarını azaltmaktadır. Bununla birlikte, kullanılmış malzemelerin geri dönüştürülerek yeniden kullanılması hem çevre hem de ekonomik nedenlerden dolayı önemlidir. Bu çalışmada, doğal ve geri dönüștürülmüș malzeme kullanılarak üretilen sandviç kompozitlerin eğilme davranışları incelenmiștir. Bu bağlamda, 3 farklı granül boyutu (1 mm, $2 \mathrm{~mm}$ ve $4 \mathrm{~mm}$ ) ve üç farklı çekirdek kalınlığı (4 mm, $8 \mathrm{~mm}$ ve $12 \mathrm{~mm}$ ) kullanılarak yapılan dokuz farklı çekirdek malzemesi kullanılmış tașıt lastiğinden imal edilmiștir. Daha sonra çekirdek malzemeler doğal jüt kumaş takviyeli tabakalı kompozitler ile birleştirilerek sandviç kompozitler üretildi. Üretilen sandviç kompozit malzemelerin yapı malzemesi olarak kullanılabilirliğini test etmek için, üç nokta eğilme yükü altında eğilme davranışları incelenmiştir. Test sonuçları, malzemenin eğilme davranışının, çekirdek malzemenin tanecik boyutuna ve kalınlığına göre değisstiğini göstermektedir.

Anahtar Kelimeler: Sandviç kompozit, eğilme modülü, eğilme dayanımı, geri dönüşüm, doğal lifler, granül boyutu, çekirdek kalınlı̆̆ı

Cite

Balcioglu, H.E. (2018). "Flexural Behaviors of Sandwich Composites Produced Using Recycled and Natural Material", Mugla Journal of Science and Technology, 4(1), 64-73.

\section{Introduction}

Natural resources such as water, forests, minerals, oil, etc. which are consumed more every day due to our crowded world could be used with recycling for a longer time. By recycling the reusable wastes and using over ground natural resources, we protect both the environment and the underground resources for future generations. In addition to this, nowadays production methods of more economical and durable materials are being investigated in order to meet the unlimited needs of people. Thereby, materials obtained by physically combining more than one material with special methods have gained importance in terms of research and using. Composite materials are formed by combining at the macro level at least two materials having different properties, which cannot dissolve in one another, in order to develop some features that are not available or limited in conventional materials. Fiber reinforced polymer matrix composite materials are used in many industrial building materials such as aerospace, automobile, defense and construction. Synthetic fibers such as glass, carbon, aramid and boron are the most commonly used reinforcing fiber types.

Alternative potentials of natural fiber reinforced polymer composites to synthetic fiber reinforced composites are increasing day by day due to reasons such as international politics of countries, environmental risks and increasing global energy crises. This situation has been a driving force in the natural fiber research topic. Usage of petroleum-based product creates the environmental problems during disposal and emission which increases interest in development of natural fiber composites for low and medium load applications. Moreover, the production costs of synthetic fibers are higher than natural fibers. Some of the fibers of plants such as jute, flax, cannabis, aloe fiber, and banana fiber is some of the natural fibers used as reinforcing phase in composite materials. Such natural fibers may be recycled or biodegraded in nature. Natural fibers are both environmentally friendly and economical in this respect. They also offer an attractive ecological alternative to glass, carbon and synthetic fibers, thanks to their mechanical performance as compared to their weight. [1]. 
Last few decades, due to environmental and health awareness, increase the using of natural fiber reinforced composites have been targeted by improve of their mechanical properties. Woven fabric reinforced natural composites have superior mechanical properties when compared to random oriented short fiber composite, it is important to enhance the physical and mechanical properties of composites for low and medium load applications [2]. Exhaustive amount of research has been carried out on the characterization of mechanical properties of different kinds of natural fiber reinforced polymer composites by reinforcing the natural fiber in short and random orientation form.

Torres et al. [3] have investigated elastic modulus, tensile strength and failure strain of short fiber and woven fabric reinforced flax/epoxy and jute/epoxy natural fibers composite, statistically. The test results show that the tensile strength and elasticity modulus of jute/epoxy and flax/epoxy composites are below the carbon/epoxy composite but close to the unit strain values required for damage. In addition, it has been found that natural composites reinforced with woven fabric have superior strength values than short fiber reinforced ones. Sailesh et al. [4] have examined the tensile, bending, impact and wear properties of kenaf-aloe vera-jute reinforced hybrid laminated natural composites having different stacking sequence. The test results show that the fiber stacking sequences and additionally the adhesion interaction between the reinforcing fiber and matrix affects directly the mechanical properties of the composite material. Rajesh and Pitchaimani [5] have investigated the effect of reinforcing natural fiber in the form of braided yarn woven fabric on mechanical properties of polymer composite. The results of braided yarn fabric composites were compared with the conventional yarn fabric composite and random oriented intimately mixed short fiber composites for the same percentage of fiber weight. Natural fiber braided yarn fabric reinforcement significantly increased the mechanical properties of the composites compared with that of the conventional woven fabric and short fiber reinforcements. Wong et al. [6] have determined the fracture characterization of short bamboo fiber reinforced thermoset composites which reinforced with three different fiber lengths and volume fractions. The test results show that the maximum fracture toughness value is obtained from composites that was reinforced with $10 \mathrm{~mm}$ fiber at $50 \%$ fiber volume. When, this value compared with pure polyester test results, it was seen that was found to be $340 \%$ improvement in fracture toughness. Also, Campilho et al. [7] have evaluated the tensile fracture behavior of adhesive joints between juteepoxy composites, by bonding with a ductile polyurethane adhesive and co-curing.

Every year, around the world, billions of vehicle tires are produced to meet people's transportation needs. Concurrently, as a result of using these produced tires, many of them became unusable in nature. According to the research, this number is about 17 million tons per year. For this reason, the question of how to handle decisively with waste tires has become a global problem for countries. [8]. Leaving the waste vehicle tires as idle in the nature causes both over ground and underground pollution (Figure 1). The properly recycling and reuse of waste tires will solve both environmental pollution and eliminate the requirement of industry that use rubber as raw material.

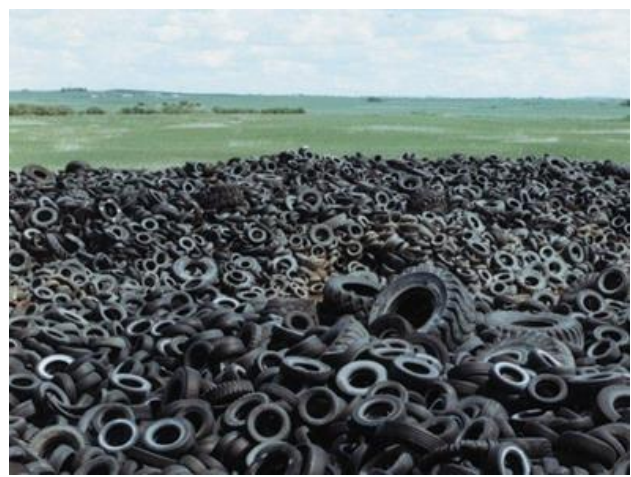

(a)

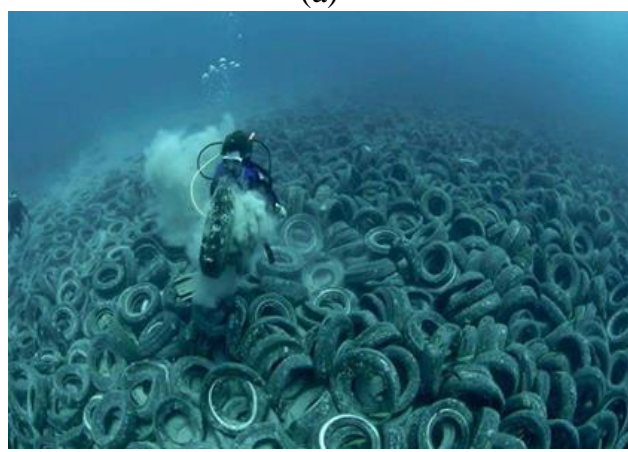

(b)

Figure 1. Pollution caused by waste vehicle tires in (a) over ground and (b) underground

Tire recycling is a recycling process for waste tires that are no longer suitable for use in vehicles by the reason of irreparable damage such as wear or tear. Since the tire material is very durable and not biodegradable, it can remain in the environment for a long time without deterioration. Burning of waste tires causes extremely harmful gases to be released. Waste tires should be sent to material recovery or energy recycling association to provide contribution to the environment and the country's economy. The waste tires are fragmentize to rubber and steel pieces in the grinding machines. The steel pieces are separated from the rubber at the magnetic conveyor. Then, the shredded rubber material is granulated in various sizes [9]. From 1994 to 2010, the European Union countries increased the recycling volume from $25 \%$ to $95 \%$ by using the majority of waste tires for energy in cement factories.[10]. The economic value of the granulated tire is more valuable than using it as fuel. New recycling technologies such as pyrolysis and devolatilization ensure that the tire is produced in granular form despite its volume and flexibility [11].

In case of out-of-plane loading, thick-walled structures are more advantageous compared to the thin. On the other hand, thick structures have a disadvantage in terms of their weight. Sandwich composites have been used in many engineering fields due to their low weight compared to their thickness since 1960s. Sandwich panels have not only advantageous in terms of weight savings and structural performance, in addition, they can be used as an effective tool to reduce costs. Generally, a sandwich structure is composed of a relatively thick, lightweight core material on the inside and a relatively 
thin, hard and durable sheet material on two outer surfaces. While honeycomb, balsa or foam are used in the core part, metal or composite material is used in sheet part. The main purpose of sandwich structures is to obtain a durable and simultaneously lightweight component. In addition, the sandwich construction can be gained features such as heat insulation or good thermal transfer, depending on the used core material in it. Furthermore, dampening of vibration and noise another important benefit provided by core materials. In recent years, the use of natural fiber reinforced polymer laminated composites as sheet materials in sandwich composite materials has become increasingly widespread. Many researches have presented studies about mechanical properties of sandwich composites. Vitale et al. [12] have investigated flexural properties and tensile and compressive failure modes of jute and glass fiber reinforced composite sandwich panels under three point bending. In order to produce sandwich composite natural fiber reinforced honeycomb and commercial PVC foam were used as cores. Jute/polyester and glass/polyester were used as sheet materials. Mallaiah et al. [13] investigated the flexural and compressive and water absorption behavior of sandwich composites having sheet material that reinforced by glass, jute, bamboo fibers, separately and together. Polyurethane foam was used as core material. The test results show that for non-hybrid samples the glass fiber reinforced sheet material has the best bending and compressive strength and the bamboo fiber is more durable than the jute fiber under the same loads. Sargianis et al. [14] investigated the acoustic response and damping performances of sandwich composite beams which sheet part made of bamboo and cotton fibers and core part made of pine and balsa. They compared the results with the results of sandwich composites having carbon fiber sheet material and Rohacell core. The test results show that it is possible to create a sandwich beam with superior acoustic performance using natural fiber based composite materials. Reis et al. [15] have performed compression, shear and bending tests in sandwich specimens having glass or jute fiber in facings and NL10 and NL30 cork agglomerates. Test results showed that the increase in the density of the cork core material was negative for the sandwich structure and that for the sandwich structure the NL10 core was better than NL30. Dwei et al. [16] have produced sandwich beams having sheet part that were made of glass fibers, recycled paper and soy-bean oil derived resin and polyurethane foam as the core for buildings applications. The natural fiber mats used to make skin material in these sandwich panels are in mat form except in the case for the recycled paper. They have investigated the behavior of the sandwich beams under the four-point bending load. The test results show that composite beams made from recycled paper have as much rigidity and rigidity as wood elements. Petrone et al. [17] have performed impact and acoustic test of honeycomb manufactured by combining short and long flax fibers with polyethylene matrix cores for sandwich panels. The test results showed that the mechanical properties of sandwich composites with core reinforced with long fibers showed $100 \%$ improvement, while damping values were reduced by $40 \%$. Mechraoui et al. [18] investigated the effect of sheet thickness, core density and sheet composition on the mechanical properties of sandwich composites having hemp/polypropylene sheet materials. The results show that the increase in fiber density in the sheet material not only improves the mechanical properties but also results in thinner cell structures in the core material.

If the concepts such as environmental pollution and production cost economics were taken in the account, recycling/reuse and use of natural fiber are becoming important in raw materials that used for sandwich composites. Concordantly, it is essential to identify new areas of use for which recycled materials and natural materials provide the desired strength. In this study, flexural behaviors of woven jute fabric reinforced natural sandwich composites, whose core part were made from waste vehicle tires, were investigated. In this context, core materials having three different thicknesses $(4 \mathrm{~mm}, 8 \mathrm{~mm}$, and $12 \mathrm{~mm})$ were produced by using granules with 3 different diameter sizes ( $1 \mathrm{~mm}, 2 \mathrm{~mm}$, and $4 \mathrm{~mm}$ ). The core material is combined with natural jute fabric reinforced laminated composite material to produce sandwich composites. The produced sandwich composites were cut according to the standards and samples were tested under three-point bending loads. The effect of granule diameter, core thickness, and fiber direction of sheet materials on the mechanical behaviors of sandwich composites were investigated.

\section{Manufacturing of Sandwich Composites}

The rubbers have properties such as flexibility, strength, high dynamic properties, easy handling, superior tear and abrasion resistance and polar liquid resistance. The rubber used in automobile tires is bendable, flexible, durable and resistant to abrasion. Granular materials, which have $1 \mathrm{~mm}$, $2 \mathrm{~mm}$ and $4 \mathrm{~mm}$ diameters size and were produced from waste vehicle tire, were used for the production of core material. The waste tires were granulated using physical methods. The granular material does not contain any piece of metal wire, which is in the structure of the tire (Figure 2a). Polipol351 mark, three component polyester resin is used to compound the granules. 1200 gr polyester resin was prepared by adding 60gr cobalt and 60gr Methyl-Ethyl-Ketone Peroxide (MEK). Prepared polyester resin is poured onto 3 $\mathrm{kg}$ of granular material and mixed with mechanical mixer (Figure 2b). Then, prepared mixture was poured into molds to produce core material having desired thickness. Finally, the molded mixture was finished by pressing in the temperature-controlled hydraulic presser at $70^{\circ} \mathrm{C}$ for $20 \mathrm{~min}$.

Table 1. Physical and mechanical properties of used matrix materials

\begin{tabular}{ccc}
\hline & Polipol351 & DTE1000 \\
\hline Density $\left(\mathrm{gr} / \mathrm{cm}^{3}\right)$ & 1.128 & 1.105 \\
Elasticity Modulus $(\mathrm{MPa})$ & 3234 & 3150 \\
Flexural Modulus $(\mathrm{MPa})$ & 4093 & 2900 \\
Tensile Strength $(\mathrm{MPa})$ & 66 & 75 \\
Flexural Strength $(\mathrm{MPa})$ & 140 & 115 \\
Elongation at Break $(\%)$ & 4.1 & 3.3 \\
\hline
\end{tabular}




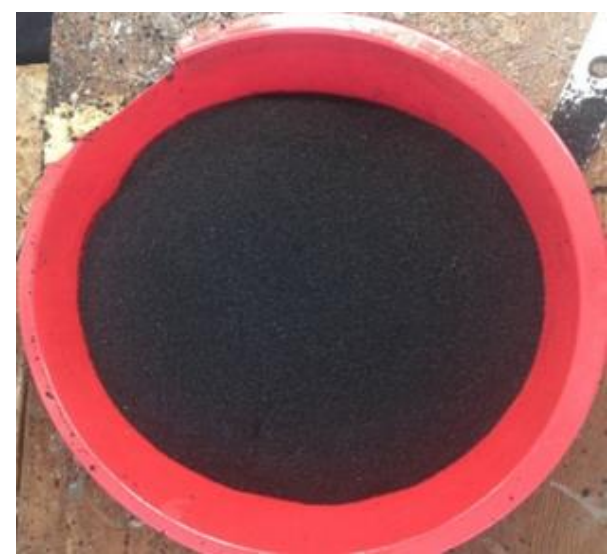

(a)

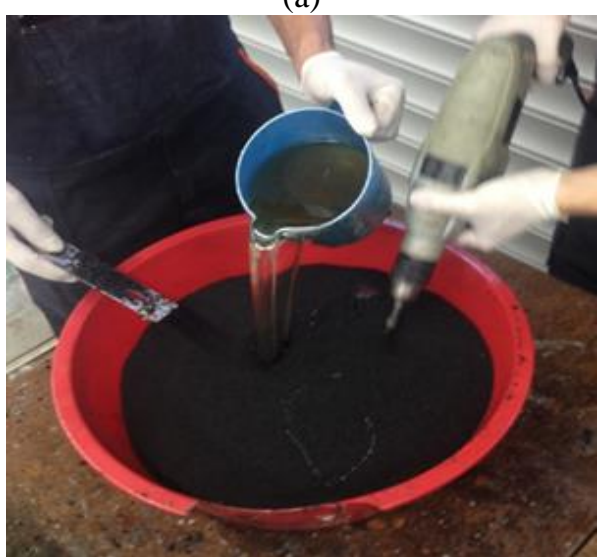

(b)

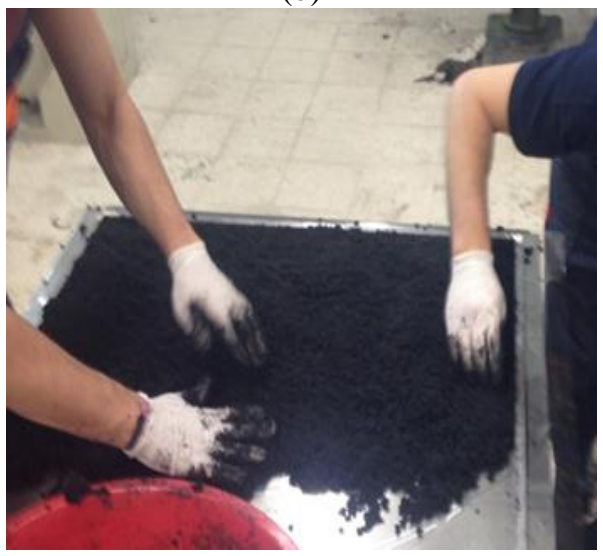

(c)

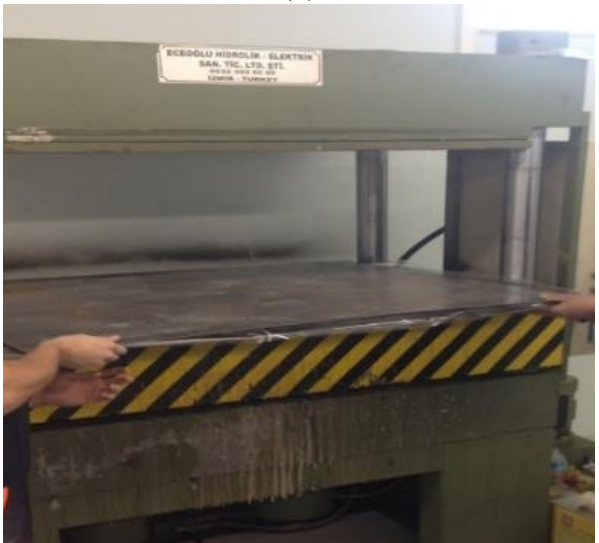

(d)

Figure 2. Manufacturing step of core materials
Jute fibers are in the front row among the natural fibers that are frequently used as reinforcing elements. Although mechanical properties such as strength and stiffness are lower than strong fibers such as flax and hemp, they can be found in abundance and at low cost compared to other cellulosic fibers. [19]. For sheet materials of sandwich composites, jute fabric reinforced laminated composites were manufactured by hand lay-up method. In this context, four layers woven jute fabrics having weight of $300 \mathrm{gr} / \mathrm{m}^{2}$ were impregnated. The fabrics are made up of Bangla Tossa $\mathrm{C}$ grade jute fibers having needle density and needle depth for the nonwoven production were 150 needle $/ \mathrm{cm}^{2}$ and 12 $\mathrm{mm}$ respectively. Epoxy resin having two components was used as matrix material. DTE 1100 epoxy and DST 1105 catalyst were used for matrix material. They were mixed in a ratio of $76 / 24$ in weight. Physical and mechanical properties of used matrix materials were given in Table 1. Epoxy resin were saturated on woven jute fabric, which is sheet material of sandwich composite, with roll (Figure 3a). Two layers of fabric were wetted by epoxy resin in order to form lower sheet and then core material was placed on the lower sheet, the upper sheet was laminated with two layers of fabric on the core (Figure 3b). Manufacturing process was made in a mold, coated with a mold release agent. Finally, the prepared semi-finished sandwich composite was cured in temperature-time-pressure controlled press at $70^{\circ} \mathrm{C}$ under a pressure of $6 \mathrm{MPa}$ along $60 \mathrm{~min}$ (Figure $3 \mathrm{c}$ ).

The information on the natural sandwich composites produced for the experimental studies is given in the Table 2. As can be seen from Table 1, three different thickness of core material $(4 \mathrm{~mm}, 8 \mathrm{~mm}$, and $12 \mathrm{~mm}$ ) were produced using three different granule diameters $(1 \mathrm{~mm}, 2 \mathrm{~mm}$, and $4 \mathrm{~mm})$. Test specimens were produced to perform mechanical tests of natural sandwich composites with a total of nine different material configurations. The density of the core material with the smallest granule diameter was found to be the highest at $9.08 \times 10^{-4} \mathrm{~g} / \mathrm{mm}^{3}$. As the granule diameter increased, the density of the core material decreased and decreased to $6.98 \times 10^{-4} \mathrm{~g} / \mathrm{mm}^{3}$. In the material configuration column, the letter $\mathrm{D}$ represents the granular diameter value and the letter $\mathrm{T}$ represents the thickness value of the core material.

Table 2. Material configuration and density of core materials

\begin{tabular}{|c|c|c|c|}
\hline $\begin{array}{l}\text { Granule } \\
\text { Diameter } \\
\text { (D) } \\
(\mathrm{mm})\end{array}$ & $\begin{array}{c}\text { Core } \\
\text { Material } \\
\text { Thickness } \\
(\mathrm{T})(\mathrm{mm})\end{array}$ & $\begin{array}{c}\text { Core } \\
\text { material } \\
\text { density } \\
(\mathrm{g} / \mathrm{mm} 3)\end{array}$ & $\begin{array}{c}\text { Abbreviation of } \\
\text { Material } \\
\text { Configuration }\end{array}$ \\
\hline 1 & $4,8,12$ & $9.08 \times 10^{-4}$ & $\begin{array}{l}\text { D1-T4, D1-T8, } \\
\text { D1-T12 }\end{array}$ \\
\hline 2 & $4,8,12$ & $7.71 \times 10^{-4}$ & $\begin{array}{l}\text { D2-T4, D2-T8, } \\
\text { D2-T12 }\end{array}$ \\
\hline 4 & $4,8,12$ & $6.98 \times 10^{-4}$ & $\begin{array}{c}\text { D4-T4, D4-T8, } \\
\text { D4-T12 }\end{array}$ \\
\hline
\end{tabular}




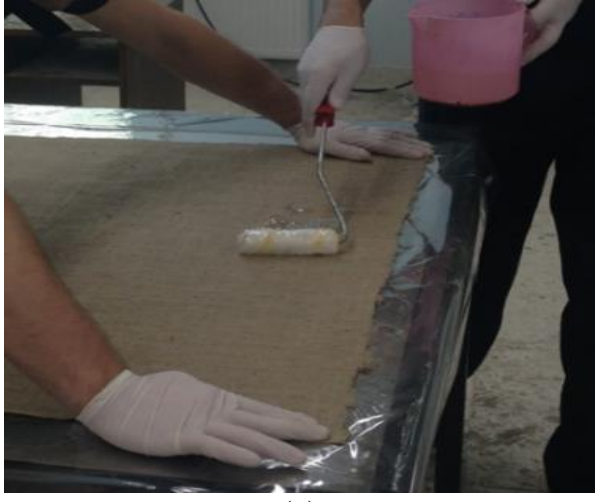

(a)

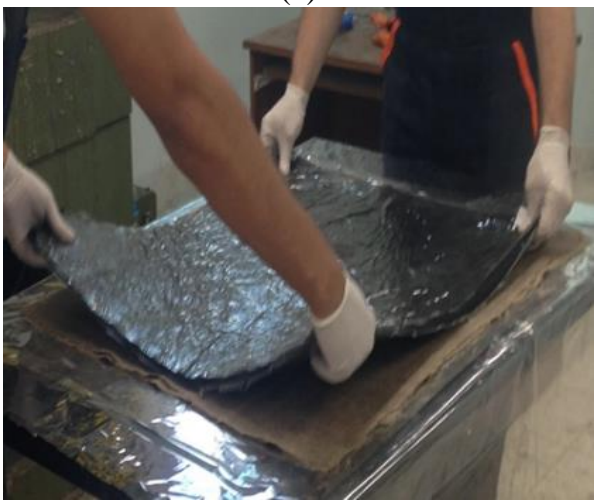

(b)

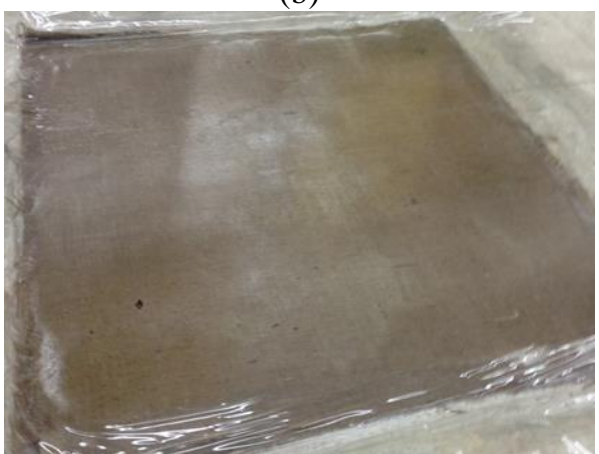

(c)

Figure 3. Manufacturing step of sandwich composite having sheet materials

\section{Flexural Test}

\subsection{Three-Point Bending Test}

The test specimens were dimensioned according to the ASTM C 393 test standard to determine the strength values of the produced natural sandwich composites such as sheet bending stress, core shear stress and sheet bending stiffness. This test method covers determination of the properties of flat sandwich constructions subjected to flatwise flexure in such a manner that the applied moments produce curvature of the sandwich facing planes [20]. Rectangular specimens were used for the tests. The specimen dimensions for the tests varied depending upon the core thickness of the specimen. Accordingly, the sample size for the $4 \mathrm{~mm}$ core thickness was $16 \times 96 \mathrm{~mm}^{2}$, the sample size for the $8 \mathrm{~mm}$ core thickness was $32 \times 128 \mathrm{~mm}^{2}$, and the sample size for the $12 \mathrm{~mm}$ core thickness was $48 \times 196 \mathrm{~mm}^{2}$. The three-point bending test specimens are sized according to the scale in Table 3 . The span length was set to be 3 times the sample width. Threepoint bending tests were performed at a crosshead speed of
$2 \mathrm{~mm} / \mathrm{min}$ compression speed by U-Test brand $50 \mathrm{kN}$ capacity universal test machine. At least five specimens were tested and force versus stroke values was recorded. Test configuration and the specimen under three-point bending load were given in Figure 5.

Table 3. Dimensions of three-point bending specimens according to core thickness

\begin{tabular}{cccc}
\hline $\begin{array}{c}\text { Core } \\
\text { Thickness }\end{array}$ & $4 \mathrm{~mm}$ & $8 \mathrm{~mm}$ & $12 \mathrm{~mm}$ \\
\hline $\begin{array}{c}\text { Specimen } \\
\text { Dimensions }\end{array}$ & $16 \times 96 \mathrm{~mm}^{2}$ & $32 \times 128 \mathrm{~mm}^{2}$ & $48 \times 196 \mathrm{~mm}^{2}$ \\
\hline
\end{tabular}

Shear loads cause severe damage in sandwich composites having flexible core. If perfect adhesion contact between the sheet and core material is assumed, the weakest component of the structure will be the first to fail under shear loading. Generally, the sheet materials are much stiffer and thinner than the core, so the shear damage stress can be assumed as the shear strength of the core. Assuming that the sheet remains bonded to the core, that the sandwich beam bends in a cylindrical manner and that cross-sections remains plane and perpendicular to the longitudinal axis of the beam, core shear stress $\left(\tau_{\mathrm{c}}\right)$ values were determined by the Equation 1 below;

$$
\tau_{c}=\frac{P}{2 h b}
$$

where $\mathrm{P}$ is damage load, $\mathrm{h}$ is distance between sheets centers, and $\mathrm{b}$ is the sandwich beam width. Sheet material bending stress $\left(\sigma_{\mathrm{s}}\right)$ is obtained by the Equation 2;

$$
\sigma_{s}=\frac{P l}{4 h b t_{s}}
$$

where $\mathrm{t}_{\mathrm{s}}$ is sheet material thickness and $l$ is the span length. The dimensions mentioned above can be seen in Figure 4 .

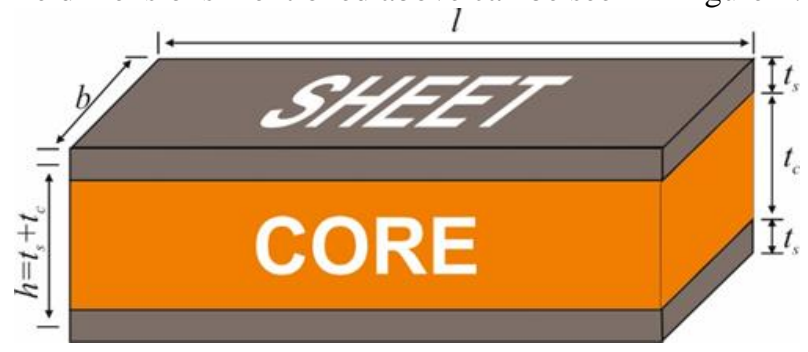

Figure 4. Sandwich structure dimensions

Also; sheet material bending stiffness (D) is obtained by the formula given below Equation 3;

$$
D=\frac{E_{S} t_{s} h^{2} b}{2}
$$

where $E_{s}$ is the sheet material modulus. In this study, the modulus of elasticity for the jute reinforced composite material has not been determined. The elasticity modulus value for jute/epoxy was taken as $6285 \mathrm{MPa}$ from the previous work of the author [21]. 


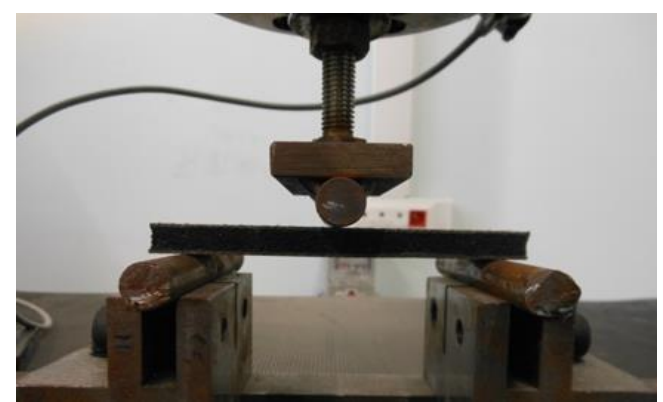

Figure 5. Three-point bending test specimen and test configuration

\subsection{Short Beam Shear Test}

Three-point bending test using short beam shear specimen is suitable as a general method of evaluation for the shear properties in sandwich composites because of its simplicity [22]. This test method was performed in accordance with ASTM D2344 test standard [23] and involves loading a short sandwich beam under three-point bending (Figure 9) to ensure shear failure of the core.

The short beam shear test (SBS) is carried out to investigate the interlaminar shear strength of natural sandwich composites. For sandwich composites, the short beam shear test is intended to measure shear strength between the core and the skins [24]. The length and width dimensions of the short beam shear test specimens vary according to the core thickness of the sample as in the three-point bending test. Short beam shear test specimens, which were given dimensions of them in Table 4, were tested under 3-point bending load. The length to thickness ratio and span to thickness ratio was 6 and 4, respectively.

Table 4. Dimensions of short beam shear test specimens according to core thickness

\begin{tabular}{cccc}
\hline $\begin{array}{c}\text { Core } \\
\text { Thickness }\end{array}$ & $4 \mathrm{~mm}$ & $8 \mathrm{~mm}$ & $12 \mathrm{~mm}$ \\
\hline $\begin{array}{c}\text { Specimen } \\
\text { Dimensions }\end{array}$ & $16 \times 48 \mathrm{~mm}^{2}$ & $24 \times 72 \mathrm{~mm}^{2}$ & $32 \times 96 \mathrm{~mm}^{2}$
\end{tabular}

Five specimens were tested and the average of these five test results was regarded as meaningful short beam strength. The short beam shear strengths were calculated according to Equation 4.

$$
\tau_{S B S}=\frac{3 P}{4 b d}
$$

Where $\mathrm{P}$ is maximum damage load, $\mathrm{b}$ and $\mathrm{d}$ are width and thickness of specimens, respectively. Figure 6 showed short beam shear test specimens and test configurations.

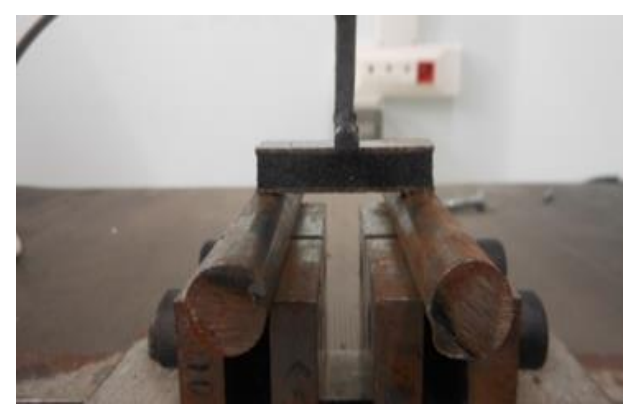

Figure 6. Short beam shear test and test configurations

\section{Results and Discussions}

In this study, the effect of granule diameter and core material thickness on the mechanical behavior of natural sandwich composite material. For this purpose, total of 9 different core materials having 3 different thicknesses $(4,8,12 \mathrm{~mm})$ were produced by using 3 different granule diameters $(1,2,4 \mathrm{~mm})$. The core material produced from the recycled material was combined with natural fibers reinforced jute/epoxy laminated sheet material. The produced environmentally friendly sandwich composites were tested under tensile and compressive loads.

\subsection{Three-Point Bending Test Results}

The variation of sheet bending stress and core shear stress were given in Figure 7 and Figure 8, respectively. The stress in the surface material varies according to the core thickness of the sandwich composite and the granule size in the core structure. These two main variables directly affect the deformation ability of sandwich composites at bending. The natural sandwich composites show a ductile behavior under three-point bending load as shown in both graphs.

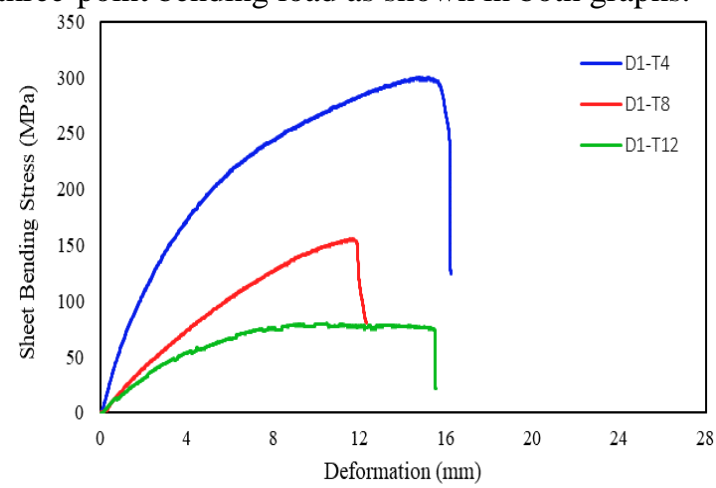

(a)

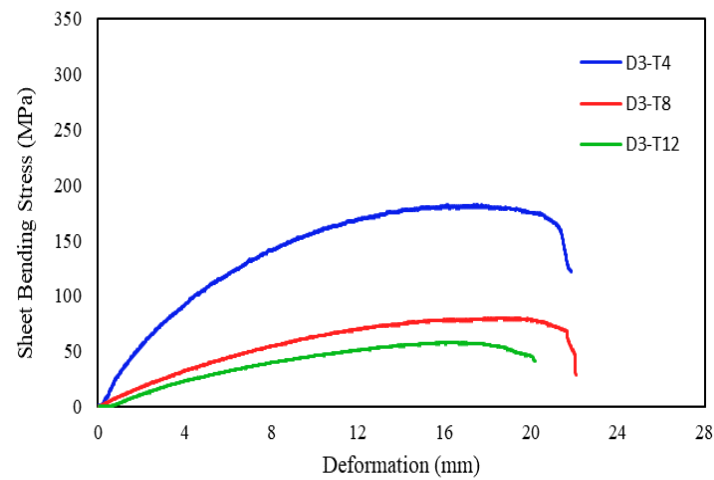

(b)

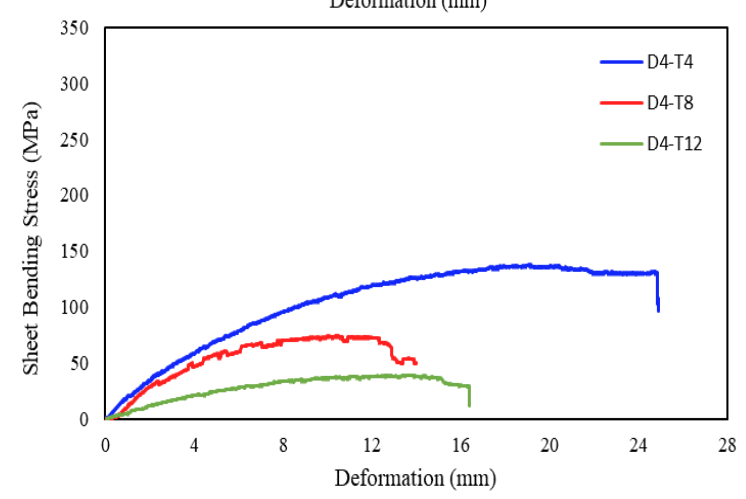

(c)

Figure 7. Sheet bending stress of specimens having core with (a) $1 \mathrm{~mm}$, (c) $2 \mathrm{~mm}$, and (e) $4 \mathrm{~mm}$ granule diameter 


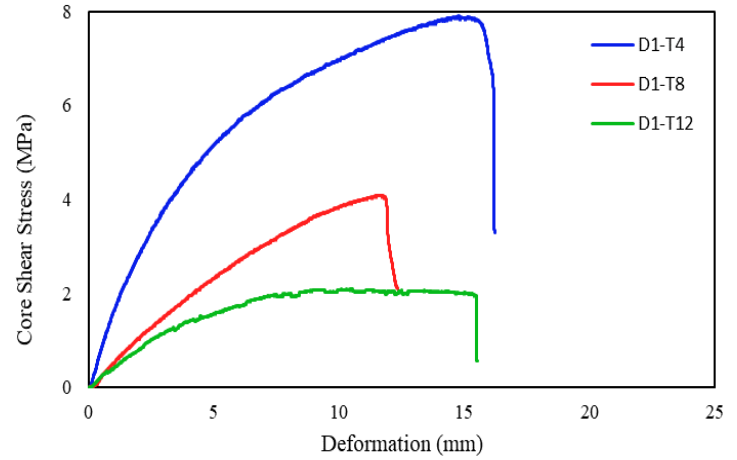

(a)

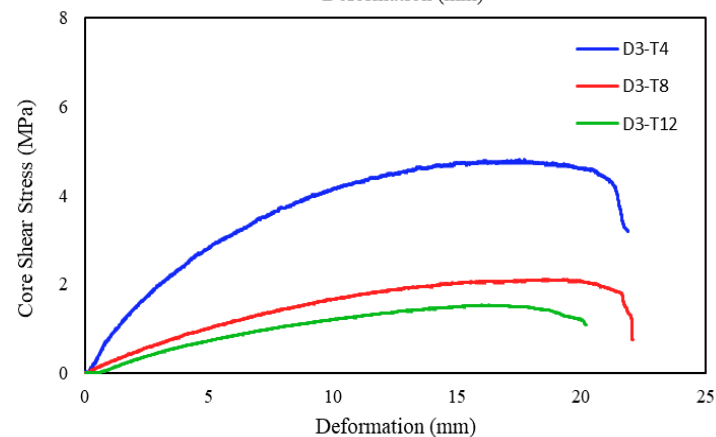

(b)

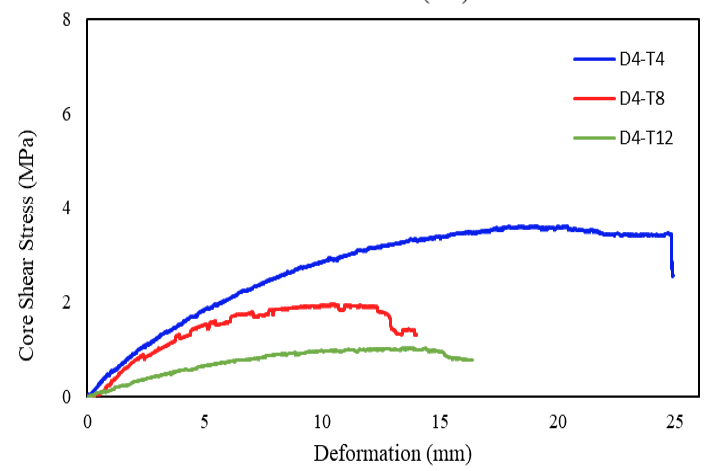

Figure 8. Core shear stress of specimens having core with

(a) $1 \mathrm{~mm}$, (b) $2 \mathrm{~mm}$, and (c) $4 \mathrm{~mm}$ granule diameter

The sheet bending strength $\left(\sigma_{S}\right)$, core shear strength $\left(\tau_{C}\right)$ and sheet bending stiffness (D) values obtained from the threepoint bending test under the Table 5 were given. The value given in parentheses is the standard deviation values obtained from the test repetitions. The maximum sheet bending stress was found as $300,208 \mathrm{MPa}$ in the sample having D1-T4 configuration. The minimum sheet bending stress was also found as $16.163 \mathrm{MPa}$ in the sample having
D4-T12 configuration. According to this, when the sheet bending strengths of the samples having the same core thickness were compared with each other, the sheet bending strengths of the samples, which had core made by using the small granular, were found higher up to $187 \%$. If similar comparison is made for sheet bending strength values of samples having the same granular size, samples with thin core were found to have a higher strength of $745 \%$.

The core material is made from granules showing elastic behavior, so it is more susceptible to deforming under load. The maximum core shear stress was found as 7,9 $\mathrm{MPa}$ in the sample having D1-T4 configuration. The minimum core stress was also found as $0,986 \mathrm{MPa}$ in the sample having D4-T12 configuration. The core shear strength is calculated using the data obtained from the sheet bending strength test. So, the core shear behavior is similar to the sheet bending behavior.

The sheet bending stiffness is not dependent on the used granule size, so it was only calculated based on the core thickness values. Hereunder, the maximum sheet bending stiffness was found as $36,081 \mathrm{Nm}^{2}$ in the sample having the thickest core (T12) and the minimum sheet bending stiffness was found as of $3,565 \mathrm{Nm}^{2}$ in the sample having the thinnest (T4) core. Such that thick specimens have 912\% more bending stiffness than thin specimens.

Table 5. Core shear strength $\left(\tau_{C}\right)$, sheet bending strength $\left(\sigma_{S}\right)$, and sheet bending stiffness $(\mathrm{D})$ of natural sandwich composites

\begin{tabular}{|c|c|c|c|c|c|c|c|c|c|}
\hline \multirow{3}{*}{$\begin{array}{c}\text { Core } \\
\text { Thickness } \\
(\mathrm{mm})\end{array}$} & \multicolumn{9}{|c|}{ Granule Diameter (mm) } \\
\hline & \multicolumn{3}{|c|}{1} & \multicolumn{3}{|c|}{2} & \multicolumn{3}{|c|}{4} \\
\hline & $\tau_{C}(M P a)$ & $\sigma_{S}(M P a)$ & $\mathrm{D}\left(\mathrm{Nm}^{2}\right)$ & $\tau_{C}(M P a)$ & $\sigma_{S}(M P a)$ & $\mathrm{D}\left(\mathrm{Nm}^{2}\right)$ & $\tau_{C}(M P a)$ & $\sigma_{S}(M P a)$ & $\mathrm{D}\left(\mathrm{Nm}^{2}\right)$ \\
\hline \multirow{2}{*}{4} & 7.900 & 300.208 & \multirow{2}{*}{3.565} & 4.784 & 181.794 & \multirow{2}{*}{3.565} & 3.596 & 136.642 & \multirow{2}{*}{3.565} \\
\hline & (1.131) & $(42.988)$ & & $(0.687)$ & $(26.099)$ & & $(0.250)$ & $(9.514)$ & \\
\hline \multirow{2}{*}{8} & 2.896 & 110.042 & \multirow{2}{*}{13.613} & 2.113 & 80.294 & \multirow{2}{*}{13.613} & 1.181 & 44.894 & \multirow{2}{*}{13.613} \\
\hline & $(0.767)$ & $(29.143)$ & & $(0.336)$ & $(12.776)$ & & $(0.070)$ & $(2.653)$ & \\
\hline \multirow{2}{*}{12} & 1.220 & 46.367 & \multirow{2}{*}{36.081} & 0.986 & 37.451 & \multirow{2}{*}{36.081} & 0.425 & 16.163 & \multirow{2}{*}{36.081} \\
\hline & $(0.076)$ & $(2.900)$ & & $(0.220)$ & $(8.378)$ & & $(0.085)$ & $(3.216)$ & \\
\hline
\end{tabular}

*(Standard deviation) 
One of the frequent damage modes in sandwich composites under three-point bending load is the collapse of the core due to the compressed local load. Such damage cannot usually be observed from outside of the sandwich composite structure, but it must be taken into account that this leads to a significant reduction in the load carrying capacity. Furthermore, the failure modes of a sandwich beam include face yielding, face wrinkling, core failure, failure of the adhesive bond and core indentation. Due to the core material is more flexible than the surface material, the surface material was damaged earlier than the core material underneath the three-point bending load (Figure 9). When the upper side of the test sample was forced to compressive under the bending load, the lower side of the sample was forced to pull at the same time. The connection between the surface and the core is weakened due to this relative stress condition. The surface material is brittle fractured with the interface weakening and increasing deformation. After the surface material has been broken, the sandwich composite test specimen has lost its force carrying capability, even if it continues to deform. Therefore, the deformation mechanism of these sandwich composite structures is strongly dominated by the mechanical properties of sandwich face sheets that are carrying loads by mainly tension/compression during sandwich beam bending.

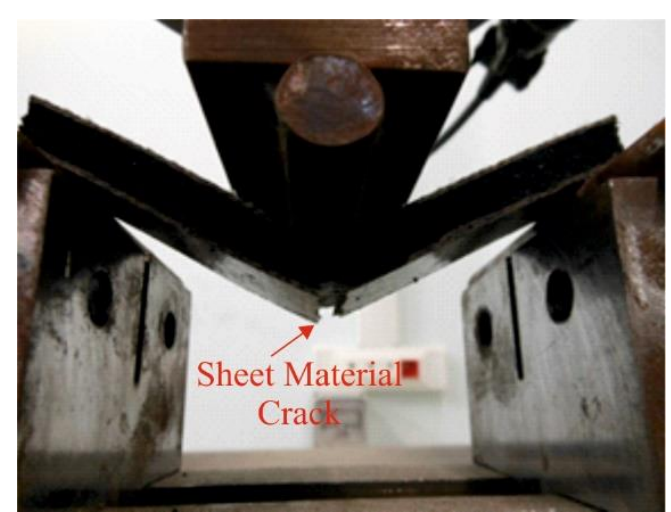

Figure 9. Three-point bending test damage of sandwich composite

Due to the mixing and molding step of the granular material with the polyester resin was performed in an open-air environment, some air gaps occurred in the core material. These air gaps caused the material to take on a porous structure. When the core thickness increases or larger granules are used, the number of pore between the granules increases. The pore between the granules form the points at which the structure begins to damage. These pores can be thought of as crack initiation points within the material. The increase in the amount of voids in the structure causes damage to the structure at lower force values. So that as, the granule size and the core thickness increased, the core shear strength decreased.

When the deformation values of the specimens having the core of different thickness that produced by using the granules of the same size were compared, it can be said that the deformation amount increases as the thickness value increases. Also, the deformation ability of the natural sandwich composites enhanced when the granule size is reduced. It can be said that this situation originated due to the good adhesion of small size granules. The deformation value has decreased as the thickening of the core material increases the number of adhesion errors caused by the production.

\subsection{Short Beam Shear Test}

For all the tested specimens, the maximum load corresponds to the failure load as the specimen failed immediately after the formation of the first shear crack in the core material. Short beam shear tests were performed under three-point bending loading. In this type of loading, the underside of the sample is forced in tension stress and the upper side is forced in compression stress. As a result of stresses, fiber breaks and bending damage occurred on sheet material, which were made of jute/epoxy laminated composite. It has also been observed that as a result of the damage, there is a tendency to separate between the sheet and the core material. The core material exhibiting elastic behavior was only showed shape deformation as a result of the compression load. However, the tensile stress that formed on the underside of the sample has weakened the resin, which held together the granules. This has resulted in the formation of cracks in the core material (Figure 10).

Table 6 summarizes the short beam shear strength of natural sandwich beam specimens. The maximum short beam shear strength was found $3.797 \mathrm{MPa}$ in samples having D1-T4 configuration. The minimum short beam shear strength was found $0.757 \mathrm{MPa}$ in samples having D4-T12 configuration. According to this, if we express the effect of granule size and core thickness on the short beam shear strength, it can be said that the short beam shear strength of specimens with core, which was manufactured by using small sized granules, was up to $28,72 \%$ higher than that of big sized granules. The short beam shear strengths of the samples with the same thickness was compared between themselves in this comparison. When similar comparison was made for the short beam shear strength of samples having core, which produced by using same granule size, it seen that short beam shear strength of samples with thin core were more durable up to $301 \%$ that that of thick core material.

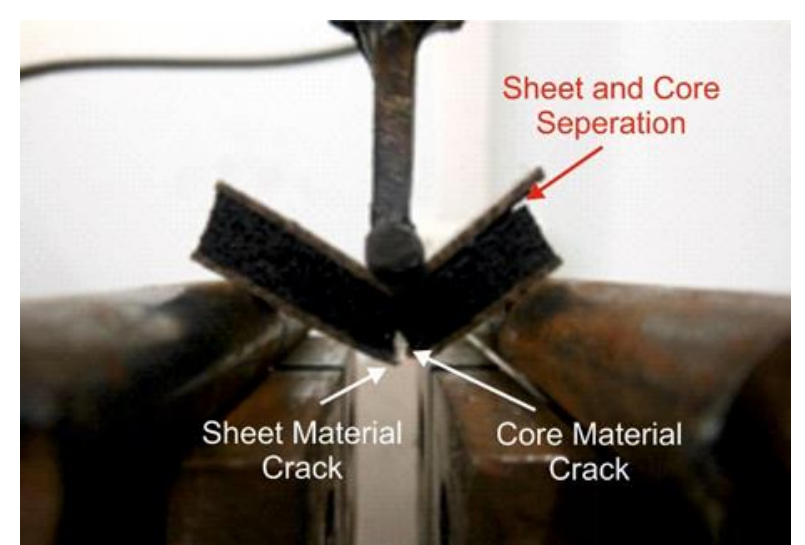

Figure 10. Types of damage observed in short beam shear test

Short beam shear behavior of natural sandwich composites is given under three-point bending load in Figure 11. When the short beam shear stress-deformation graphs were examined, it can be said that the specimens show ductile behavior in general. In almost all test groups, the sample continued to deform when applied load reached maximum 
value named damage load. After the core material began to lose its elasticity and began to disintegrate, SBS stress declined rapidly.

Table 6. Short beam strength of natural sandwich composites

\begin{tabular}{cccc}
\hline $\begin{array}{c}\text { Core } \\
\text { Thickness } \\
(\mathrm{mm})\end{array}$ & \multicolumn{3}{c}{ Granule Size (mm) } \\
\cline { 2 - 4 } & 3.797 & 2.289 & 4 \\
\hline \multirow{2}{*}{4} & $(0.047)$ & $(0.541)$ & $(0.315)$ \\
& 1.844 & 1.621 & 1.514 \\
8 & $(0.151)$ & $(0.221)$ & $(0.166)$ \\
& 1.062 & 0.878 & 0.757 \\
12 & $(0.058)$ & $(0.072)$ & $(0.137)$ \\
\hline
\end{tabular}

\section{*(Standard Deviation)}

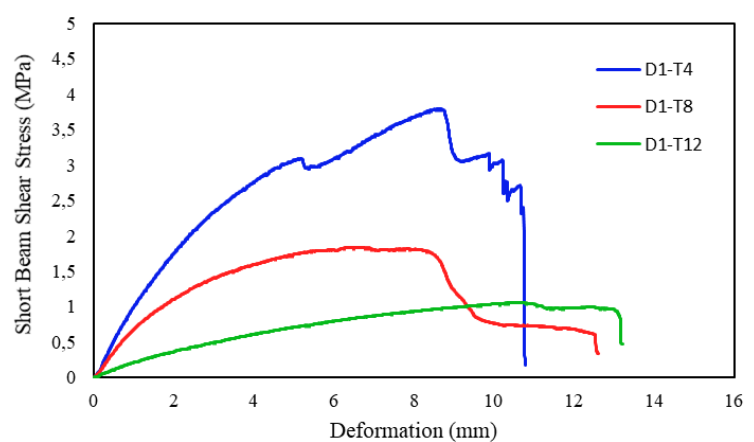

(a)

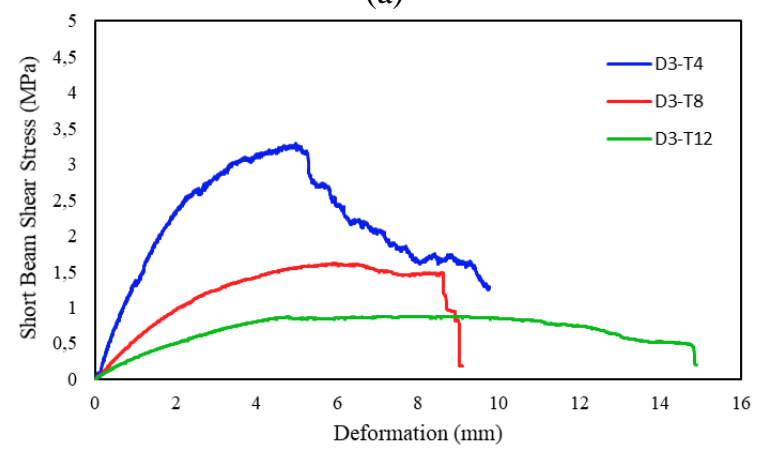

(b)

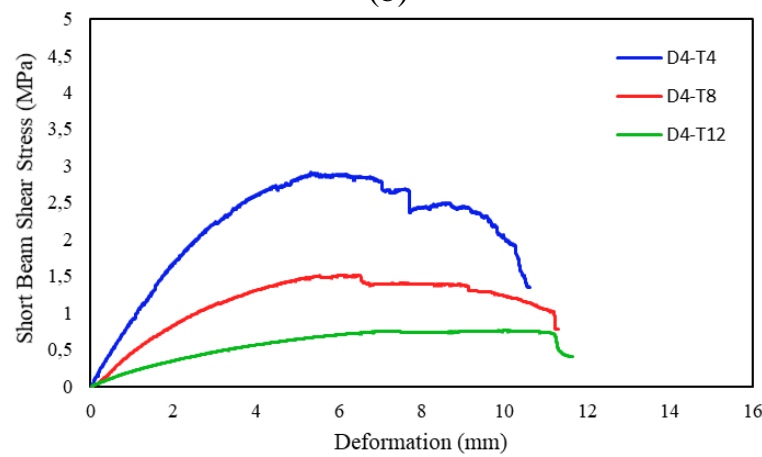

(c)

Figure 11. Short beam shear stress of specimens having core with (a) $1 \mathrm{~mm}$, (b) $2 \mathrm{~mm}$, and (c) $4 \mathrm{~mm}$ granule diameter

\section{Conclusions}

In this study, flexural behaviors of natural sandwich composites produced from used vehicle tires and natural jute fiber woven fabric were investigated. In this context, the effects of granule diameter, core thickness on the flexural strength and shot beam shear strength have been investigated, experimentally. The concluding remarks can be summarized as follows:

- Although the sample sizes were different in both types of flexural test, similar damage mechanisms occurred in natural sandwich composites for the same type of load. Damage mechanisms such as sheet-core interface separation, sheet material crack and core material breakage in the samples progressed, respectively under the three-point loading. In addition, the granules, the main component of the core material, can be elastic under load and highly deformable. The deformability of the core material is directly related to the size of these granules. For this reason, there is no problem of disintegration of the granules during dissolution of the core material.

- Among the samples having same thickness, the sheet bending strength, core strength and short beam shear strength of natural sandwich composites having core material made from fine granule is higher.

- Among samples having the same granule diameter, the sheet bending strength, core strength and short beam shear strength of natural sandwich composites with thicker core is lower.

- The coarse granules have a lower adhesion quality, although they have a larger surface area than fine granules. Damage under load was progressing starting from the gaps between the granules. In fine grained structures the damage starts at higher force values as there are less inter-granular voids.

- Thick core material had more errors and voids due to adhesive joining, according to thin core material. Therefore, the mechanical strengths of natural sandwich composites having thick core material are lower under three-point bending load.

- It can be said that the sandwich composites that have the core and sheet part, which were produced from the used vehicle tire and the natural jute fiber respectively, can be used for low and medium load levels.

\section{References}

[1] Elanchezhian C., Ramnath B. V., Ramakrishnan G., Rajendrakumar M., Naveenkumar V., and Saravanakumar M. K., "Review on mechanical properties of natural fiber composites.," Mater. Today Proc., vol. 5, no. 1, pp. 17851790,2018

[2] Rajesh M. and Kanish T., "Mechanical Properties of Natural Fiber Sandwich Composite: Effect of Core Layer," Mech. Mater. Sci. Eng. MMSE J. Open Access, vol. 9, pp. 1-5, 2017.

[3] Torres J. P., Vandi L.-J., Veidt M., and Heitzmann M. T., "The mechanical properties of natural fibre composite laminates: A statistical study," Compos. Part Appl. Sci. Manuf., vol. 98, pp. 99-104, Jul. 2017.

[4] Sailesh A., Arunkumar R., and Saravanan S., "Mechanical Properties and Wear Properties of Kenaf - Aloe Vera - Jute Fiber Reinforced Natural Fiber Composites," Mater. Today Proc., vol. 5, pp. 7184-7190, 2018.

[5] Rajesh M. and Pitchaimani J., "Mechanical Properties of Natural Fiber Braided Yarn Woven Composite: 
Comparison with Conventional Yarn Woven Composite," J. Bionic Eng., vol. 14, no. 1, pp. 141-150, Jan. 2017.

[6] Wong K. J., Zahi S., Low K. O., and Lim C. C., "Fracture characterisation of short bamboo fibre reinforced polyester composites," Mater. Des., vol. 31, no. 9, pp. 41474154, Oct. 2010.

[7] Campilho R. D. S. G., Moura D. C., Gonçalves D. J. S., da Silva J. F. M. G., Banea M. D., and da Silva L. F. M., "Fracture toughness determination of adhesive and co-cured joints in natural fibre composites," Compos. Part B Eng., vol. 50, pp. 120-126, Jul. 2013.

[8] Czajczyńska D., Krzyżyńska R., Jouhara H., and Spencer N., "Use of pyrolytic gas from waste tire as a fuel: A review," Energy, vol. 134, pp. 1121-1131, Sep. 2017.

[9] United States Environmental Protection Agenc, Scrap Tire Handbook on Recycling Management for US and Mexico. Washington, 2010.

[10] Sienkiewicz M., Kucinska-Lipka J., Janik H., and Balas A., "Progress in used tyres management in the European Union: A review," Waste Manag., vol. 32, no. 10, pp. 17421751, Oct. 2012.

[11] Wimmer Z. and Zarevúcka M., "A review on the effects of supercritical carbon dioxide on enzyme activity," Int. J. Mol. Sci., vol. 11, no. 1, pp. 233-253, 2010.

[12] Vitale J. P., Francucci G., Xiong J., and Stocchi A., "Failure mode maps of natural and synthetic fiber reinforced composite sandwich panels," Compos. Part Appl. Sci. Manuf., vol. 94, pp. 217-225, Mar. 2017.

[13] Mallaiah S., Sharma K. V., and Krishna M., "Development and comparative studies of bio-based and synthetic fiber based sandwich structures," Int J Soft Compos Eng, vol. 2, pp. 332-5, 2012.

[14] Sargianis J. J., Kim H.-I., Andres E., and Suhr J., "Sound and vibration damping characteristics in natural material based sandwich composites," Compos. Struct., vol. 96, pp. 538-544, Feb. 2013.

[15] Reis L., Carvalho P., Alves C., and Freitas M., "Mechanical Behaviour of Sandwich Beams Manufactured with Glass or Jute Fiber in Facings and Cork Agglomerates as Core," Mater. Sci. Forum, vol. 636-637, pp. 245-252, Jan. 2010.

[16] Dweib M. A., Hu B., O’Donnell A., Shenton H. W., and Wool R. P., "All natural composite sandwich beams for structural applications," Compos. Struct., vol. 63, no. 2, pp. 147-157, Feb. 2004.

[17] Petrone G., Rao S., De Rosa S., Mace B. R., Franco F., and Bhattacharyya D., "Initial experimental investigations on natural fibre reinforced honeycomb core panels," Compos. Part B Eng., vol. 55, pp. 400-406, Dec. 2013.

[18] Mechraoui A., Riedl B., and Rodrigue D., "Mechanical properties of polypropylene structural foams with fiberreinforced skins," J. Cell. Plast., vol. 47, no. 2, pp. 115-132, Mar. 2011.

[19] Karaduman Y. and Onal L., "Flexural behavior of commingled jute/polypropylene nonwoven fabric reinforced sandwich composites," Compos. Part B Eng., vol. 93, pp. 12-25, May 2016.

[20] ASTM C-393, "Standard Test Method for Flexural Properties of Sandwich Constructions," ASTM International, 2000.

[21] Karabulut N., Aktaș M., and Balcıoğlu H. E., "Surface Modification Effects on the Mechanical Properties of
Woven Jute Fabric Reinforced Laminated Composites," J. Nat. Fibers, pp. 1-15, Jan. 2018.

[22] Sideridis E. and Papadopoulos G. A., "Short-beam and three-point-bending tests for the study of shear and flexural properties in unidirectional-fiber-reinforced epoxy composites," J. Appl. Polym. Sci., vol. 93, no. 1, pp. 6374, Jul. 2004.

[23] Setyawan P. D., Sugiman, and Saputra Y., "Characterization of compressive and short beam shear strength of bamboo opened cell foam core sandwich composites," AIP Conference Proceedings 1717, 2016.

[24] D. ASTM, "Standard Test Method for Short-Beam Strength of Polymer Matrix Composite Materials and Their Laminates," ASTM International, 2000. 